\title{
Maturing Technologies for Stirling Space Power Generation
}

Scott D. Wilson and Brentley C. Nowlin

Glenn Research Center, Cleveland, Ohio

Michael W. Dobbs

Vantage Partners, LLC, Brook Park, Ohio

Paul C. Schmitz

Power Computing Solutions, Inc., Avon Lake, Ohio

James Huth

Converter Source, LLC, Athens, Ohio 


\section{NASA STI Program . . . in Profile}

Since its founding, NASA has been dedicated to the advancement of aeronautics and space science. The NASA Scientific and Technical Information (STI) Program plays a key part in helping NASA maintain this important role.

The NASA STI Program operates under the auspices of the Agency Chief Information Officer. It collects, organizes, provides for archiving, and disseminates NASA's STI. The NASA STI Program provides access to the NASA Technical Report Server-Registered (NTRS Reg) and NASA Technical Report ServerPublic (NTRS) thus providing one of the largest collections of aeronautical and space science STI in the world. Results are published in both non-NASA channels and by NASA in the NASA STI Report Series, which includes the following report types:

- TECHNICAL PUBLICATION. Reports of completed research or a major significant phase of research that present the results of NASA programs and include extensive data or theoretical analysis. Includes compilations of significant scientific and technical data and information deemed to be of continuing reference value. NASA counter-part of peer-reviewed formal professional papers, but has less stringent limitations on manuscript length and extent of graphic presentations.

- TECHNICAL MEMORANDUM. Scientific and technical findings that are preliminary or of specialized interest, e.g., "quick-release" reports, working papers, and bibliographies that contain minimal annotation. Does not contain extensive analysis.
- CONTRACTOR REPORT. Scientific and technical findings by NASA-sponsored contractors and grantees.

- CONFERENCE PUBLICATION. Collected papers from scientific and technical conferences, symposia, seminars, or other meetings sponsored or co-sponsored by NASA.

- SPECIAL PUBLICATION. Scientific, technical, or historical information from NASA programs, projects, and missions, often concerned with subjects having substantial public interest.

- TECHNICAL TRANSLATION. Englishlanguage translations of foreign scientific and technical material pertinent to NASA's mission.

For more information about the NASA STI program, see the following:

- Access the NASA STI program home page at http://www.sti.nasa.gov

- E-mail your question to help@sti.nasa.gov

- $\quad$ Fax your question to the NASA STI Information Desk at 757-864-6500

- Telephone the NASA STI Information Desk at 757-864-9658

- Write to:

NASA STI Program

Mail Stop 148

NASA Langley Research Center Hampton, VA 23681-2199 
NASA/TM-2016-219415

\section{Maturing Technologies for Stirling Space Power Generation}

Scott D. Wilson and Brentley C. Nowlin

Glenn Research Center, Cleveland, Ohio

Michael W. Dobbs

Vantage Partners, LLC, Brook Park, Ohio

Paul C. Schmitz

Power Computing Solutions, Inc., Avon Lake, Ohio

James Huth

Converter Source, LLC, Athens, Ohio

Prepared for the

14th International Energy Conversion Engineering Conference (IECEC) sponsored by AIAA

Salt Lake City, Utah, July 25-27, 2016

National Aeronautics and

Space Administration

Glenn Research Center

Cleveland, Ohio 44135 


\section{Acknowledgments}

This work is funded through the NASA Science Mission Directorate and the Radioisotope Power Systems Program Office. The authors wish to acknowledge Gina Dugala and Martin Fraeman for their contributions to the DCC TRA. Any opinions, findings, conclusions, or recommendations expressed in this article are those of the authors and do not necessarily reflect the views of NASA. The authors wish to acknowledge the task leads for their commitments and contributions to Stirling Technology Research.

This report is a formal draft or working paper, intended to solicit comments and ideas from a technical peer group.

This report contains preliminary findings, subject to revision as analysis proceeds.

Trade names and trademarks are used in this report for identification only. Their usage does not constitute an official endorsement, either expressed or implied, by the National Aeronautics and Space Administration.

Level of Review: This material has been technically reviewed by technical management.

Available from

NASA STI Program

Mail Stop 148

NASA Langley Research Center

Hampton, VA 23681-2199
National Technical Information Service 5285 Port Royal Road Springfield, VA 22161 703-605-6000

This report is available in electronic form at http://www.sti.nasa.gov/ and http://ntrs.nasa.gov/ 


\title{
Maturing Technologies for Stirling Space Power Generation
}

\author{
Scott D. Wilson and Brentley C. Nowlin \\ National Aeronautics and Space Administration \\ Glenn Research Center \\ Cleveland, Ohio 44135 \\ Michael W. Dobbs \\ Vantage Partners, LLC \\ Brook Park, Ohio 44142 \\ Paul C. Schmitz \\ Power Computing Solutions, Inc. \\ Avon Lake, Ohio 44012 \\ James Huth \\ Converter Source, LLC \\ Athens, Ohio 45701
}

\begin{abstract}
Stirling Radioisotope Power Systems (RPS) are being developed as an option to provide power on future space science missions where robotic spacecraft will orbit, flyby, land or rove. A Stirling Radioisotope Generator (SRG) could offer space missions a more efficient power system that uses one fourth of the nuclear fuel and decreases the thermal footprint of the current state of the art. The RPS Program Office, working in collaboration with the U.S. Department of Energy (DOE), manages projects to develop thermoelectric and dynamic power systems, including Stirling Radioisotope Generators (SRGs). The Stirling Cycle Technology Development (SCTD) Project, located at Glenn Research Center (GRC), is developing Stirling-based subsystems, including convertors and controllers. The SCTD Project also performs research that focuses on a wide variety of objectives, including increasing convertor temperature capability to enable new environments, improving system reliability or fault tolerance, reducing mass or size, and developing advanced concepts that are mission enabling. Research activity includes maturing subsystems, assemblies, and components to prepare them for infusion into future convertor and generator designs. The status of several technology development efforts are described here. As part of the maturation process, technologies are assessed for readiness in higher-level subsystems. To assess the readiness level of the Dual Convertor Controller (DCC), a Technology Readiness Assessment (TRA) was performed and the process and results are shown. Stirling technology research is being performed by the SCTD Project for NASA's RPS Program Office, where tasks focus on maturation of Stirling-based systems and subsystems for future space science missions.
\end{abstract}

\section{Nomenclature}

ACT Advanced Cooling Technologies

ACU ASC Controller Unit

ASC Advanced Stirling Convertor

ASRG Advanced Stirling Radioisotope Generator

DCC Dual Convertor Controller

DOE Department of Energy

(-E3) Engineering design \#3

(EU2) Engineering Unit design \#2

GPHS General Purpose Heat Source

GRC Glenn Research Center

HTLA High-Temperature Linear Alternator

LMSSC Lockheed Martin Space Systems Company

MLI Multi-Layer Insulation

NPR NASA Procedural Requirements

RCHS Radial Core Heat Spreader 
RHU Radioisotope Heater Unit

RPS Radioisotope Power Systems

SCTDP Stirling Cycle Technology Development Project

TRA Technology Readiness Assessment

TRL Technology Readiness Level

VCHP Variable Conductance Heat Pipe

\section{Stirling Cycle Technology Development Project}

Stirling Radioisotope Power Systems (RPS) are being developed by NASA's RPS Program in collaboration with the U.S. Department of Energy (DOE). SRGs could provide power to future space science missions where robotic spacecraft will orbit, flyby, land or rove. The Stirling Cycle Technology Development (SCTD) Project is funded by the RPS Program to develop Stirling-based subsystems, including convertors and controller maturation efforts that have resulted in high fidelity hardware like the Advanced Stirling Radioisotope Generator (ASRG), Advanced Stirling Convertor (ASC), and ASC Controller Unit (ACU). The SCTD Project also performs research to develop less mature technologies with a wide variety of objectives, including increasing temperature capability to enable new environments, improving system reliability or fault tolerance, reducing mass or size, and developing advanced concepts that improve buying position or are mission enabling.

The ASRG was developed by the DOE, Lockheed Martin Space Systems Company (LMSSC), Glenn Research Center (GRC), and Sunpower, Inc. from 2007 to 2013. DOE initiated termination of that contract in late 2013 due to budget constraints, but significant progress had been made in preparing hardware for electrically heated system level demonstration before the ASRG flight development project ended. In 2014, NASA GRC completed the build and assembly of the ASRG Engineering Unit design \#2 (EU2) (Refs. 1 and 2). The electrically-heated system test characterized performance and efficiency, control authority of the controller, disturbance force measurement with varying piston phase and piston amplitude, and effect of spacecraft DC bus voltage variation on EU2 performance (Ref. 3).

The ASRG major subsystems included two convertors, two heat sources, one controller, and a generator housing assembly. The housing provided electrical, mechanical and thermal interfaces for the controller, convertors, and heat sources. The ASRG design did not include some of the technologies that are being developed under the research segment of the SCTD Project, namely the variable conductance heat pipe (VCHP), radial core heat spreader (RCHS), and an active balancer. Figure 1 shows a general layout of the major ASRG subsystems as well as the VCHP, RCHS, and balancer, as they might be integrated into the ASRG. The lines that connect each box to the housing represents electrical, mechanical, or thermal interfaces. The integration of research technologies could improve system fault tolerance to a convertor failure or enable turning off one or both convertors. Inclusion of a balancer and two VCHPs would increase the overall mass while using RCHSs would reduce the overall mass. Brief descriptions of the VCHP, RCHS, and balancers are included here, along with updates on other research technologies being matured. Table 1 summarizes research technologies and potential benefit to an ASRG-like generator design. More details on each technology are also provided. The VCHP, RCHS, and balancer would provide new capability that could improve system reliability or fault tolerance and reduce mass or size. The HTLA, MLI, and DCC provide alternatives to existing ASRG-like subsystems that could increase temperature capability to enable new environments, reduce mass or size, and develop advanced concepts that improve the NASA's buying position. Benefits are noted for each technology, along with concerns that would need to be quantified as part of system trades.

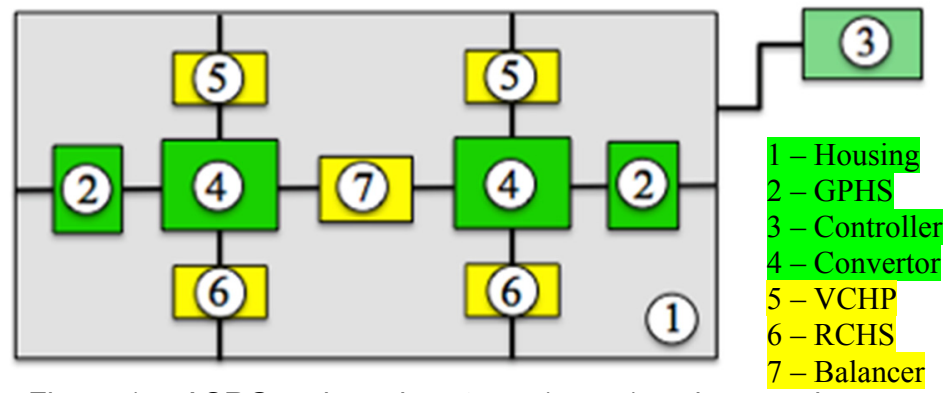

Figure 1.-ASRG major subsystems (green) and research technologies (yellow). 
TABLE 1.-SUMMARY OF STIRLING RESEARCH TECHNOLOGIES

\begin{tabular}{|c|c|c|c|c|}
\hline Name & Objective & Relevance & Benefits & Considerations \\
\hline $\begin{array}{l}\text { Variable Conductance } \\
\text { Heat } \mathrm{Pipe}_{\mathrm{i}}(\mathrm{VCHP})\end{array}$ & $\begin{array}{l}\text { Improve system } \\
\text { reliability or } \\
\text { fault tolerance }\end{array}$ & $\begin{array}{l}\text { There was no similar } \\
\text { capability in the ASRG } \\
\text { design, in the case of a } \\
\text { failed convertor, the } \\
\text { ASRG insulation was } \\
\text { designed to degrade and } \\
\text { allow heat to escape the } \\
\text { GPHS }\end{array}$ & $\begin{array}{l}\text { - Maintains heat } \\
\text { source temperatures } \\
\text { and insulation } \\
\text { integrity when one } \\
\text { Stirling is not } \\
\text { operating } \\
\text { - Passive heat source } \\
\text { cooling system could } \\
\text { simplify CONOPS }\end{array}$ & $\begin{array}{l}\text { - Mass penalty } \\
\text { - System reliability } \\
\text { penalty } \\
\text { - Sensitivity to high } \\
\text { constant acceleration } \\
\text { needs to be } \\
\text { quantified }\end{array}$ \\
\hline $\begin{array}{l}\text { Radial Core Heat } \\
\text { Spreader (RCHS) }\end{array}$ & $\begin{array}{l}\text { Reduce mass or } \\
\text { size }\end{array}$ & $\begin{array}{l}\text { ASRG used the cold-side } \\
\text { adapter flange on ASC } \\
\text { Radial heat pipes have } \\
\text { not been implemented on } \\
\text { Stirling engine heat } \\
\text { rejection }\end{array}$ & $\begin{array}{l}\text { - Performance } \\
(1,000 \mathrm{~W} / \mathrm{K}) \\
\text { - Mass savings }(4 \mathrm{x}) \text {, } \\
\text { even greater benefit } \\
\text { for higher power } \\
\text { generators } \\
\text { - Manufacturing time } \\
\text { is low } \\
\text { - Cost is low }\end{array}$ & $\begin{array}{l}\text { - Sensitivity to high } \\
\text { constant acceleration } \\
\text { - Impact of minimum } \\
\text { activation } \\
\text { temperature }\left(50^{\circ} \mathrm{C}\right) \\
\text { needs to be assessed }\end{array}$ \\
\hline - $=1=16$ & $\begin{array}{l}\text { Improve system } \\
\text { reliability or } \\
\text { fault tolerance }\end{array}$ & $\begin{array}{l}\text { There was no similar } \\
\text { capability in the ASRG } \\
\text { design, the disturbance } \\
\text { force of one convertor } \\
\text { would be transferred to } \\
\text { the spacecraft in the case } \\
\text { of a failed convertor }\end{array}$ & $\begin{array}{l}\text { - Enables mission to } \\
\text { continue if one } \\
\text { convertor fails } \\
\text { - Could reduce case } \\
\text { motion and piston } \\
\text { excursions during } \\
\text { launch }\end{array}$ & $\begin{array}{l}\text { - Mass penalty } \\
\text { - System reliability } \\
\text { net gain needs to be } \\
\text { assessed } \\
\text { - Additional } \\
\text { controller integration } \\
\text { cost and complexity }\end{array}$ \\
\hline $\begin{array}{l}\text { High-Temp Linear } \\
\text { Alternator }\end{array}$ & $\begin{array}{l}\text { Increase } \\
\text { temperature } \\
\text { capability to } \\
\text { enable new } \\
\text { environments }\end{array}$ & $\begin{array}{l}\text { ASRG used the ASC } \\
\text { alternator design, capable } \\
\text { to } 130^{\circ} \mathrm{C}\end{array}$ & $\begin{array}{l}\text { - Provides } 70^{\circ} \mathrm{C} \\
\text { margin for ASRG } \\
\text { - Enables use in } \\
\text { higher temperature } \\
\text { environments }\end{array}$ & $\begin{array}{l}\text { - Thermal cycling } \\
\text { endurance needs to } \\
\text { be assessed }\end{array}$ \\
\hline Multi-Layer Ins & $\begin{array}{l}\text { Reduce mass or } \\
\text { size }\end{array}$ & $\begin{array}{l}\text { ASRG used Microtherm } \\
\text { HT microporous } \\
\text { insulation which was } \\
\text { suitable for multi- } \\
\text { mission environments } \\
\text { MLI is only suitable for } \\
\text { vacuum environments }\end{array}$ & $\begin{array}{l}\text { - Smaller size for } \\
\text { equal performance } \\
\text { - Mass savings }\end{array}$ & $\begin{array}{l}\text { - Requires vacuum } \\
\text { environment so not } \\
\text { suitable for planetary } \\
\text { surfaces without } \\
\text { vacuum containment }\end{array}$ \\
\hline $\begin{array}{l}\text { Dual Convertor } \\
\text { Controller }\end{array}$ & $\begin{array}{l}\text { Develop } \\
\text { advanced } \\
\text { concepts that } \\
\text { are mission } \\
\text { enabling }\end{array}$ & $\begin{array}{l}\text { ASRG used the ACU: } 3 \mathrm{x} \\
\text { cards, one convertor per } \\
\text { card, fault tolerant, } \\
\text { convertor piston phase } \\
\text { control } \\
\text { DCC: } 2 \mathrm{x} \text { cards, two } \\
\text { convertors per card, fault } \\
\text { tolerant, no convertor } \\
\text { piston phase control }\end{array}$ & $\begin{array}{l}\text { - Enables hot-swap } \\
\text { - Lower development } \\
\text { cost } \\
\text { - High hardware } \\
\text { fidelity (prototype) }\end{array}$ & $\begin{array}{l}\text { - No piston phase } \\
\text { control so convertors } \\
\text { must be sufficiently } \\
\text { matched, as were } \\
\text { ASC engineering } \\
\text { models }\end{array}$ \\
\hline
\end{tabular}




\section{A. Variable Conductance Heat Pipe (VCHP)}

The VCHP has been developed to enable passive heat transfer from the General Purpose Heat Source (GPHS) to the generator housing when convertors are not operating, like during fueling or in the event of a convertor failure. The VCHP would maintain an acceptable GPHS temperature range and prevent fouling of the microporous insulation package. With a focus on improving system fault tolerance, Small Business Innovative Research (SBIR) funded efforts have applied advanced analysis and testing to demonstrate a breadboard design. With a scaled version of the VCHP attached to the heater head of an ASC-1HS, the Stirling convertor was started and allowed to achieve steady state at a VCHP vapor temperature at $780{ }^{\circ} \mathrm{C}$ and the convertor cold end at $36^{\circ} \mathrm{C}$. The convertor was then turned off and the VCHP was allowed to transfer heat to the radiator interfacing the cold side of the convertor. The test successfully demonstrated four start/stop cycles where the Stirling heater head temperature reached the design point of $825{ }^{\circ} \mathrm{C}$. The test also quantified the system thermal penalty of the breadboard VCHP to be thermal 5 watts, due to parasitic losses (Ref. 4).

\section{B. Radial Core Heat Spreader (RCHS)}

The cold-side adapter flange (CSAF) is a copper assembly attached to the heat rejection zone on the ASC. The CSAF provides structural support for the convertor and a heat transfer path to conduct heat from the Stirling cycle to the mounting features on the general housing assembly. The Radial Core Heat Spreader (RCHS), a two-phase titanium and water heat pipe, has been developed as a low cost, low mass, high performance alternative to the ASC CSAF. Tests have been conducted in numerous relevant environments to characterize performance in both vertical and horizontal orientations, including a sounding rocket launch in 2015 that successfully demonstrated operation during high random vibration loads and 6 min in microgravity (Ref. 5).

\section{Vibration Reduction (Balancer)}

Generator designs that incorporate a dual-opposed configuration of two Stirling convertors could experience a convertor failure, in which case the dynamic disturbance forces created by the power piston and displacer internal moving components of the operating convertor would exceed spacecraft requirements. To improve system fault tolerance, an active vibration reduction system has been demonstrated to reduce the peak dynamic disturbance force of the ASC over a range of operating conditions, including piston amplitude and temperature. The test effort reduced the peak dynamic disturbance force of an ASC from $323 \mathrm{~N}$ to $7 \mathrm{~N}$ (Ref. 6). An active vibration reduction system could also be implemented on small RPS missions that require only one convertor (Ref. 7).

\section{High-Temperature Linear Alternator (HTLA) and High-Temperature Organics}

Candidate magnets and organic materials have been screened and evaluated for service above the ASC-E3 maximum allowable alternator housing exterior surface temperature of $130{ }^{\circ} \mathrm{C}$ (Ref. 8). Before 6-month evaluations began, screening tests were used to identify the best of several commercial organic materials for their processability, short-term thermal stability, outgassing potential, and functional integrity. Materials evaluated include shrink tubing, liquid thread locker used as a secondary locking mechanism, adhesives, and O-rings. For epoxy adhesives, the Henkel Hysol EA9394C-2 epoxy paste was selected over the 3M AF131-2 supported film epoxy adhesive for use in the HTLA, due to a more stable bonding properties with aging time. Also, NEOMAX N32EZ magnets were selected due to their relatively high temperature resistance of $220^{\circ} \mathrm{C}$, which varies with load. Task objectives include demonstrating HTLA functionality at temperatures above $160^{\circ} \mathrm{C}$, characterizing alternator performance at $200{ }^{\circ} \mathrm{C}$, and identifying degradation modes for material used in the construction of the alternator during extended exposures at $200{ }^{\circ} \mathrm{C}$. Characterization testing has been completed over a range of temperatures up to $200{ }^{\circ} \mathrm{C}$ and the test rig has completed over 3,000 hours of the 5,000 hour extended operation test without any quantifiable degradation (Ref. 9).

\section{E. Multi-Layer Insulation (MLI)}

MLI could be an effective means of generator insulation in environments where radiation is the primary form of heat transfer, such as to the vacuum of space. The potential mass savings for MLI has been estimated at $20 \%$, compared to ASRG's microporous insulation. A proof of concept was fabricated from thin layers of low emissivity stainless steel, separated by layers of quartz cloth used to prevent direct contact between the metallic radiation shields. Testing was performed in a vacuum environment, where the hot-end temperature of a Stirling thermal simulator was varied from 350 to $750{ }^{\circ} \mathrm{C}$. The insulation was not as efficient as predicted due to an unanticipated increase in emissivity of the stainless steel radiation shields, cause by sublimated Nickel oxide from other test components. While this was an unexpected result, the test was still able to demonstrate a roughly equal insulation efficiency for about $1 / 3$ of the volume (Ref. 6). 


\section{F. Dual Convertor Controller (DCC)}

The Single Convertor Controller (SCC) and Dual Convertor Controller (DCC) were developed by Johns Hopkins University/Applied Physics Laboratory (JHU/APL) and GRC to actively control a single ASC and pair of ASC units, respectively. The SCC has completed performance testing and over 20,000 hours of extended duration testing while controlling a single ASC-L and the DCC has completed verification testing where it was connected to the RPS Systems Integration Lab (RSIL). The RSIL is a test environment designed to evaluate electrical interactions between a Stirling generator, electrical controller, power bus, and representative spacecraft electrical loads. Verification testing included operating a spacecraft bus in capacitive, battery, and supercapacitor configurations. The test effort demonstrated control authority and fault tolerance while controlling ASC on a spacecraft bus (Ref. 10). As part of the maturation process, technologies are assessed for readiness in higher-level subsystems. To assess the readiness level of the Dual Convertor Controller (DCC), a Technology Readiness Assessment (TRA) was performed and is described in a later section.

\section{G. Small RPS Concepts}

Small RPS concepts have been studied for potential use on deep space missions with lower power requirements (Refs. 11 and 12). Some Stirling-based small RPS concepts have been studied to characterize performance and reliability aspects for power systems that could be applied to missions containing only one GPHS or one or more Radioisotope Heater Units (RHUs). In addition to deep space probes, small RPSs are being proposed to power distributed instruments on planetary surfaces, like weather stations that measure pressure, temperature, disturbance force, optical characteristics, and wind (Ref. 13). Table 2 shows some concepts under consideration with Stirling hot-end and cold-end temperatures and estimated power output levels. The table includes a single array for two different types of modular array concepts, where insulation and housing is not shown. Also shown in the table is a single convertor concept that could utilize a single or multiple RHUs.

The Modular Stirling Radioisotope Generator (MSRG) concept contains multiple parallel Stirling convertor/controller strings and a single GPHS module in each array (Ref. 14). The arrays are stackable to enable heat source sharing and the design can tolerate $25 \%$ of the convertors failing and still provide full power output. Analysis results estimate that 1 to 8 GPHS modules could be used to produce 50 to 450 watts DC power output for the spacecraft. Each array contains four Stirling convertors arranged around each GPHS module. The convertors could be balanced individually or in dual-opposed pairs, could be radiatively or compression coupled to the GPHS modules, and would reject heat through the housing/radiator.

The Double-Acting Stirling concept is also modular and could be stacked to enable higher power generators. The novel compact arrangement of a double-acting free piston Stirling convertor could have inherent high convertor reliability. Additionally, the array design could conceptually utilize two convertors for each GPHS and continue to operate with one convertor failure, improving overall system reliability. The convertor design was developed by Converter Source, LLC under a Phase I SBIR contract. While typical free-piston Stirling engines contain pistondisplacer pairs and use gas bearing or flexure strategies to manage wear of reciprocating and close-fitting internal components, this new double-acting arrangement eliminates the displacer while reducing the number of distinct convertor parts. With focus on durability and robustness, key design features of the new convertor include a combined piston and alternator assembly to simplify fabrication and non-contacting gas bearings able to employ less tight

TABLE 2.-SOME SMALL RPS STIRLING CONCEPTS

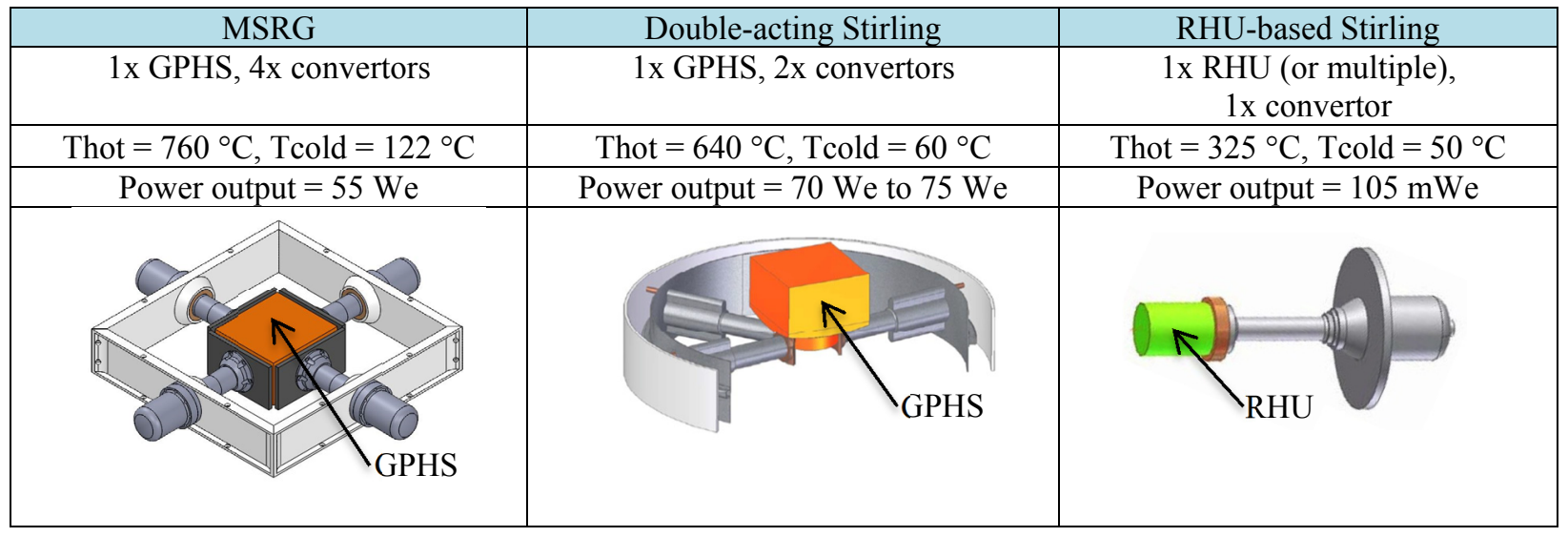


machining tolerances. Each array contains two Stirling convertors arranged around each GPHS module. Like the MSRG, the array can be dynamically balanced, radiatively coupled to the GPHS modules, and would reject heat through the housing/radiator. A Phase II SBIR is in progress to enable breadboard testing in a laboratory environment.

RHU-based Stirling concepts are also being developed for spacecraft requiring very low power, between roughly $100 \mathrm{mWe}$ to $1 \mathrm{We}$. The milliwatt design shown in the table was the product of a 2005 SBIR and contains a moving coil alternator with flexure bearings and a diaphragm piston. The convertor was designed to accept about 60 to $70 \%$ of the $1 \mathrm{Wt}$ available from a RHU heat source, resulting in a relatively low hot-end temperature of around $300{ }^{\circ} \mathrm{C}$ and power output $105 \mathrm{mWe}$. The proof of concept resulted a roughly $80 \%$ efficient moving coil alternator, which could be further optimized for higher efficiencies. This and other designs are being researched for low power applications.

\section{Technology Readiness Assessment of the Dual Convertor Controller}

Technology readiness assessments (TRAs) can be convened in many ways, including project/task self-assessment, project/task independent assessment through a peer review process, and program independent outside assessment. These assessments are used to quantify the TRL of maturing technologies and identify tasks to enable use on a flight mission. Evaluating TRL 6 involves assessing functionality for all subsystems, assemblies, and components across interfaces. Without having demonstrated functionality at a system level, TRL 4 and 5 can be demonstrated at the assembly level and do not necessarily address the interaction with other elements of the system (Ref. 15). To assess TRL, the system, subsystem, assembly, or component is decomposed and evaluated for each functional element of hardware, software, or combination. Each functional aspect is then evaluated as being a critical technology element (CTE) or not. CTEs are evaluated against TRL criteria, resulting in an answer to each question of either pass or fail. If a CTE passes all questions, it is able to achieve a TRL grade. If one CTE question is failed, that CTE is assessed in the same manner at the next lower TRL. If all CTEs pass evaluation, the system, subsystem, assembly, or component achieves an overall TRL grade. This approach is described as identification of the "weakest link", an approach detailed in Section 4.7.2.d of NASA Procedural Requirements (NPR) 7120.8.

A TRA was requested for the DCC by the SCTD Project to enable planning activity. The primary objective of this TRA was to assess the level of readiness of the DCC and its functional elements. The secondary objective was to identify forward work necessary to achieve TRL 5 , which could make this controller available to prototype subsystem testing with a generator. The DCC TRA process was formulated to achieve these objectives, based heavily on guidance received from the ASRG TRA board, chaired by M.A. Frerking (JPL) in April 2015. That guidance was later published in Reference 15 under the same author.

\section{A. TRA Process}

The Dual Convertor Controller (DCC) was jointly developed by Johns Hopkins University's Applied Physics Laboratory (APL) and GRC. The DCC is a relatively high fidelity subsystem that has completed testing and analysis to evaluate electrical interactions between convertors, electrical controller, power bus, and representative spacecraft electrical loads. The TRA was based on tailoring NPR 7123.1B (w/change 2) and a calculation tool developed by James Bilbro for the Air Force Research Laboratory (AFRL) (Refs. 16 and 17). The TRA was intended to evaluate the technology readiness level of the DCC against the existing DCC System Requirements Document (SRD), which was based on the requirements for the APL Single Convertor Controller (SCC) with additional relevant inputs from ASRG program documents and widely used standards for space flight equipment. Figure 2 shows the various steps for the tailored TRA process.

The TRA process was formulated to show conformance to TRL descriptions and exit criteria based on tailoring NPR 7123.1B. The technical team was required to define requirements, environments, and functional elements in steps 2 to 4. More mature technologies might have system requirements or specifications while less mature technologies might only have a notional mission life cycle. In step 5, functional elements were evaluated to determine if they qualify as new technologies and any new technologies were evaluated as critical technology elements.

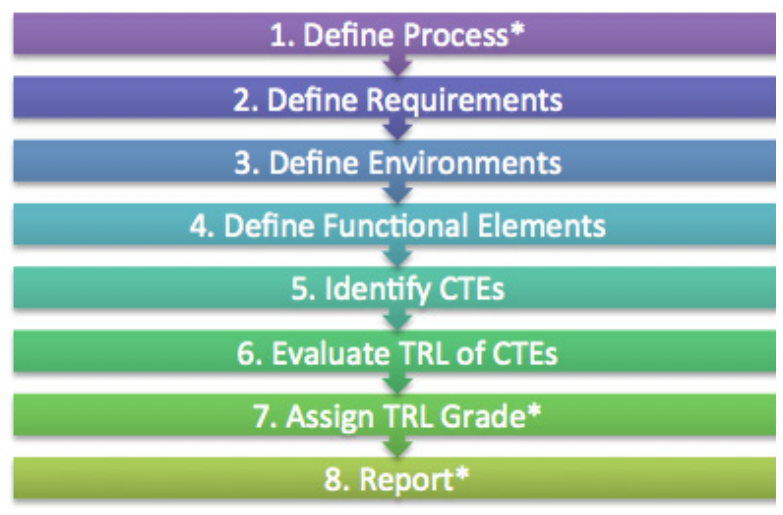

Figure 2.-Technology readiness assessment process. Asterisk denotes actions performed by the DCC TRA Board. 
Figure 3 shows the functional element assessment gates for meeting the heritage, engineering development, or new technology classifications and the resulting CTEs from evaluation of DCC functional elements. Also shown are criteria for how to arrive at a decision if something should be considered a critical technology element. In the grading column, the user is asked if a functional element is a new or novel implementation, is bound by flight heritage, or is bound by engineering development efforts to prepare that function element for use in a mission. Heritage questions ask if a functional element implementation is bounded by flight demonstrated functionality (H1), fit/form (H2), environments (H3), and manufacturing processes (H4). If any of the answers are no, the user defaults to the questions listed under engineering development. Engineering development questions ask if a functional element implementation is bound by standard engineering practices to demonstrate functionality (E1), fit/form (E2), environments (E3), and final integration (E4). If any of the engineering development criteria are failed, that functional element is classified as a new technology. Once a technology has been identified as being a New Technology, additional questions ask if the technology is essential and if there are any major risks. The user must answer if the system depends on the new technology element to meet operational requirements (C1) and if the new technology element poses a significant cost or schedule risk (C2). The last question (C2) can be very difficult to answer because the cost and schedule risks associated with technology development project are considerably different from a flight development project. Given the context of this TRA and without specific flight project requirements to define cost and schedule, question C2 was omitted for this assessment. Doing so ensured that no CTE was excluded in error based on misinterpretation of project cost and schedule drivers. If the questions define a functional element as a New Technology but not a CTE, the functional element is considered to be engineering development. Four of the eight DCC functional elements were defined as CTEs.

Heritage:
Operationally demonstrated
(ANDs)
H1 - Demonstrated
performance/function
H2 - Demonstrated fit/form
H3 - Demonstrated environment
H4 - Demonstrated manufac.
processes

Heritage:

(ANDs)

H2 - Demonstrated fit/form

H4 - Demonstrated manufac.

Engineering Development:
Bounded by demonstrated
capability (ANDs)
E1 - Demonstrated
perform./function
E2 - Demonstrated fit/form
E3 - Demonstrated environment
E4 - Demonstrated integration

New Technology: Application is new or novel

E4 - Demonstrated integration
Critical Technology Elements: New Technology Element $\underline{\text { AND }}$

$\mathrm{C} 1-$ The system depends on the new technology element to meet operational requirements

$\underline{\text { AND }}$

$\mathrm{C} 2$ - The new technology element poses a major cost or schedule risk (relevant to flight only)

\begin{tabular}{|c|c|c|c|c|c|c|c|}
\hline \# & Functional element & Function & $\begin{array}{l}\text { Grading: heritage, } \\
\text { engineering } \\
\text { development, or new } \\
\text { technology? }\end{array}$ & Grading rationale & $\begin{array}{l}\text { (C1) Essential } \\
\text { to system } \\
\text { operational } \\
\text { requirements? }\end{array}$ & $\begin{array}{c}(\mathrm{C} 2) \\
\text { Elevated } \\
\text { risk? } \\
\text { (flight) }\end{array}$ & $\begin{array}{c}\mathrm{CTE}(\mathrm{Y} / \mathrm{N}) ? \\
\text { Provide rationale }\end{array}$ \\
\hline 1 & $\begin{array}{l}\text { Conversion of the } \\
\text { ASC AC power into } \\
\text { DC power }\end{array}$ & $\begin{array}{l}\text { Noted in } \\
\text { DCC TRA } \\
\text { Report }\end{array}$ & $\begin{array}{l}\text { Engineering } \\
\text { development }\end{array}$ & $\begin{array}{l}\text { Not heritage } \\
\mathrm{H} 2 \text { : new fit/form }\end{array}$ & Yes & $\mathrm{n} / \mathrm{a}$ & $\begin{array}{l}\text { No, passes E1, } \\
\text { E2, E3, and E4 }\end{array}$ \\
\hline 2 & ASC Control & $\begin{array}{l}\text { Noted in } \\
\text { DCC TRA } \\
\text { Report }\end{array}$ & New technology & $\begin{array}{l}\text { Not engineering dev. } \\
\text { E4: new } \\
\text { implementation }\end{array}$ & Yes & $\mathrm{n} / \mathrm{a}$ & Yes to $\mathrm{C} 1$ \\
\hline 3 & ASC Synchronization & $\begin{array}{l}\text { Noted in } \\
\text { DCC TRA } \\
\text { Report }\end{array}$ & New technology & $\begin{array}{l}\text { Not engineering dev. } \\
\text { E4: new } \\
\text { implementation }\end{array}$ & Yes & $\mathrm{n} / \mathrm{a}$ & Yes to $\mathrm{C} 1$ \\
\hline 4 & Startup power & $\begin{array}{l}\text { Noted in } \\
\text { DCC TRA } \\
\text { Report }\end{array}$ & $\begin{array}{l}\text { Engineering } \\
\text { development }\end{array}$ & $\begin{array}{l}\text { Not heritage } \\
\text { H2: new fit/form }\end{array}$ & Yes & $\mathrm{n} / \mathrm{a}$ & $\begin{array}{l}\text { No, passes E1, } \\
\text { E2, E3, and E4 }\end{array}$ \\
\hline 5 & $\begin{array}{l}\text { "Repairability" from } \\
\text { time of fueling until } \\
\text { launch ("hot swap") }\end{array}$ & $\begin{array}{l}\text { Noted in } \\
\text { DCC TRA } \\
\text { Report } \\
\end{array}$ & New technology & $\begin{array}{l}\text { Not engineering dev. } \\
\text { E4: new } \\
\text { implementation }\end{array}$ & Yes & $\mathrm{n} / \mathrm{a}$ & Yes to $\mathrm{C} 1$ \\
\hline 6 & $\begin{array}{l}\text { RS- } 422 \text { command and } \\
\text { telemetry }\end{array}$ & $\begin{array}{l}\text { Noted in } \\
\text { DCC TRA } \\
\text { Report }\end{array}$ & Heritage & $\begin{array}{l}\text { Used on many } \\
\text { spacecraft }\end{array}$ & Yes & $\mathrm{n} / \mathrm{a}$ & $\begin{array}{l}\text { No, passes } \mathrm{H} 1 \text {, } \\
\mathrm{H} 2, \mathrm{H} 3 \text {, and } \\
\mathrm{H} 4\end{array}$ \\
\hline 7 & $\begin{array}{l}\text { Fault Detection and } \\
\text { Recovery }\end{array}$ & $\begin{array}{l}\text { Noted in } \\
\text { DCC TRA } \\
\text { Report }\end{array}$ & New technology & $\begin{array}{l}\text { Not engineering dev. } \\
\text { E4: new } \\
\text { implementation }\end{array}$ & Yes & $\mathrm{n} / \mathrm{a}$ & Yes to $\mathrm{C} 1$ \\
\hline 8 & $\begin{array}{l}\text { Emergency Shunt } \\
\text { Resistor }\end{array}$ & $\begin{array}{l}\text { Noted in } \\
\text { DCC TRA } \\
\text { Report }\end{array}$ & $\begin{array}{l}\text { Engineering } \\
\text { development }\end{array}$ & $\begin{array}{l}\text { Not heritage } \\
\text { H2: new fit/form }\end{array}$ & Yes & $\mathrm{n} / \mathrm{a}$ & $\begin{array}{l}\text { No, passes E1, } \\
\text { E2, E3, and E4 }\end{array}$ \\
\hline
\end{tabular}

Figure 3.-Resulting CTEs from evaluation of DCC functional elements. 
Each newly defined CTE was evaluated against a set of TRL questions in step 6. TRL 4 questions are shown in Figure 4. After each CTE has been evaluated, the subsystem was graded based on the lowest TRL of its CTE's. In step 7, the board reviewed inputs submitted by the technical team for answers to CTE definition and TRL answers. The board also reviewed evidence for TRL questions in the form of system requirements, design, test plans/procedures, and test reports. The board conducted an evaluation and provided feedback for agreement or disagreement to technical team answers to TRL 4 and TRL 5 questions. Also, a comparison of system requirements between DCC and ASRG ACU was developed. While the board acknowledged the DCC SRD was intentionally different in some ways from the ASRG Specification, the comparison was used by the board to identify missing or poorly defined

\begin{tabular}{|c|l|c|}
\hline$\#$ & \multicolumn{1}{|c|}{ TRL 4 Questions } & Y/N \\
\hline 1 & $\begin{array}{l}\text { Concept/application translated into detailed component/breadboard } \\
\text { level design? }\end{array}$ & $\mathrm{Y}$ \\
\hline 2 & Component/breadboard level fabrication completed? & $\mathrm{Y}$ \\
\hline 3 & Preliminary definition of operational environment completed? & $\mathrm{Y}$ \\
\hline 4 & $\begin{array}{l}\text { Laboratory tests and test environments defined for } \\
\text { component/breadboard testing? }\end{array}$ & $\mathrm{Y}$ \\
\hline 5 & $\begin{array}{l}\text { Pre-test predictions of component/breadboard performance in a } \\
\text { laboratory environment? }\end{array}$ & $\mathrm{Y}$ \\
\hline 6 & $\begin{array}{l}\text { Key parameter performance metrics established for } \\
\text { component/breadboard tests? }\end{array}$ & $\mathrm{Y}$ \\
\hline 7 & $\begin{array}{l}\text { Laboratory test support equipment and facilities completed for } \\
\text { component/breadboard testing? }\end{array}$ & $\mathrm{Y}$ \\
\hline 8 & $\begin{array}{l}\text { Component/breadboard successfully demonstrated in a laboratory } \\
\text { environment? }\end{array}$ & $\mathrm{Y}$ \\
\hline 9 & $\begin{array}{l}\text { Analysis of test results completed and documented verifying } \\
\text { performance relative to predictions? }\end{array}$ & $\mathrm{Y}$ \\
\hline 10 & \begin{tabular}{l} 
Preliminary system requirements for end user's application defined? \\
\hline 11
\end{tabular} & $\begin{array}{l}\text { Relevant test environment defined and documented? } \\
\text { Y }\end{array}$ \\
\hline 12 & $\begin{array}{l}\text { Critical test environments and performance predictions defined } \\
\text { relative to the preliminary definition of the operating environments? }\end{array}$ & $\mathrm{Y}$ \\
\hline
\end{tabular}

Figure 4.--Resulting CTEs from evaluation of functional elements. requirements. Observations and recommendations were developed from that comparison and numerous differences were identified. There were three major observations made by the board, which are summarized in the next section.

\section{B. DCC TRL Grade}

The controller's primary functions are to match ASC electrical loads and convert the AC power of the ASC to DC power used by the space vehicle electric power system bus. The technical team had identified eight functional elements, based on DCC requirements and major components. A detailed definition of each functional element is documented in the DCC TRA Report. The functional elements are: 1) AC-DC conversion, 2) ASC control, 3) ASC Synchronization, 4) startup power, 5) repairability, 6) RS-422 command and telemetry, 7) fault detection and recovery, and the 8) emergency shunt resistor. Only the following functional elements were defined as CTEs: ASC control, ASC Synchronization, repairability and fault detection and recovery. The TRL questions were answered for each CTE. At that point, the technical team provided inputs to the board for review. The board agreed with the inputs but there were some conditions applied to agreement with the initial grading. Those observations are described here in limited detail while the TRA Report contains a more detailed description.

1. Observation \#1-Hardware Status: The DCC hardware was defined as Engineering Model in the SRD. Based on process definitions taken from NPR 7123, the board defined the hardware status as prototype. It is acknowledged that the hardware is high fidelity and is likely part prototype and part engineering model, or a combination of TRL 6 and 7. However, the definition of Engineering Model contains the language, "and are built and tested so as to establish confidence that the design will function in the expected environments." This language requires the unit to be able to test in operational environments, including random vibration, shock, and thermal vacuum. The DCC is unable to test in the noted environments.

2. Observation \#2-Operational Environments: Even though "generic" mission requirements are acceptable from TRL 1-4 and "generic or specific class of missions" for TRL 5, as described in Reference 15, it is acknowledged that the DCC SRD was based on specific requirements from the ASRG ACU Specification. While differences may have been intentional by the DCC SRD authors, the board considered some requirements to be important for future potential development efforts and may warrant review and revision to 
reduce risk of requirements gaps between eventual end-user requirements. Until end-user requirements are available, developers should be cognizant of the risk of requirement gaps at higher levels of development, namely TRL 6. Some storage, transportation, and EDL load requirements were found to be lacking in the DCC SRD and are considered important operational environments for future development efforts. The board agreed with TRL 4 Question \#2 but recommended the SRD be reviewed for adequate definition before starting TRL 6.

3. Observation \#3-Integration: After verification testing was completed in January 2016, the technical team identified an issue with integrating the DCC into the RSIL environment. Investigation is ongoing to identify the root cause but the issue was not present when testing the SCC or DCC outside of the RSIL. This issue does not affect any identified CTE but does affect the successful implementation of the DCC into the RSIL. The board recommended this issue be resolved and recognized the risk that resolution could include design changes to DCC functional elements or the creation of a new functional element, in which case reevaluation at TRL 4 would be necessary.

The DCC was designed as a subsystem of an ASRG-like space power system. A TRA was initiated by the SCTD Project to evaluate TRLs 3-5 for the DCC while controlling two ASCs with 55-turn coil alternators. The TRA focused on the subsystem, without consideration of system level interactions that would normally be included in assessment of TRL 6. Based on an evaluation of critical technology elements against TRL evaluation criteria, the TRA board recommended that the DCC subsystem be graded at TRL 4 for the particular ASC design tested. Figure 5 shows the TRL grading for each CTE. The CTEs are colored green because they passed TRL 4 criteria while the DCC box is colored yellow, due to the risk described in Observation \#3. If the integration issue is resolved without the DCC requiring design changes that affect the functional elements or create new ones, the TRA grading can achieve TRL 4.

The DCCs were modified in 2015 to be compatible with ASCs containing both 55-turn and 77-turn alternator coil designs. Verification testing of the DCC has not yet been completed while controlling ASCs with 77-turn coil alternators so TRL 4 questions 8 and 9 do not have any input for that implementation. If TRL 4 questions 8 and 9 can be completed while controlling ASCs with 77-turn coil alternators, the TRA grading for that implementation can achieve TRL 4.

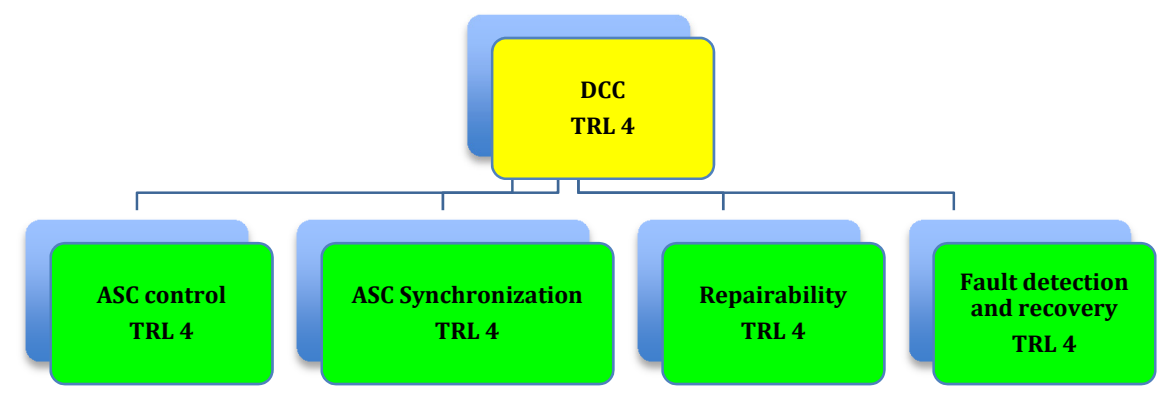

Figure 5.-TRL grades for DCC critical technology elements. 


\section{Conclusion}

The RPS Program Office is working in collaboration with the U.S. Department of Energy (DOE) to develop RPS systems for space science missions. The Stirling Cycle Technology Development (SCTD) Project is developing Stirling conversion technology like convertors, controllers, and supporting technologies that focus on a wide variety of objectives, including increasing convertor temperature capability, improving system reliability/fault tolerance, reducing mass/size, and developing advanced concepts. Research activity includes maturing subsystems, assemblies, and components to prepare them for infusion into future convertor and generator designs. As part of the maturation process, technologies are assessed for readiness in higher-level subsystems. To assess the readiness level of the Dual Convertor Controller (DCC), a Technology Readiness Assessment (TRA) was performed. The boarded graded the DCC at TRL 4 with observations and recommendations for future work. Stirling technology research tasks focus on maturating Stirling-based systems and subsystems for future space science missions.

\section{References}

1. Wong, W.A., Wilson, K., Smith, E., Collins, J., "Pathfinding the Flight Advanced Stirling Convertor Design With the ASC-E3," Proceedings of the Tenth International Energy Conversion Engineering Conference (IECEC), AIAA, Atlanta, GA, August 2012.

2. Oriti, S.M., "Advanced Stirling Radioisotope Generator Engineering Unit 2 (ASRG EU2) Final Assembly," Proceedings from the 2015 Nuclear and Emerging Technologies for Space, Albuquerque, NM, 2015.

3. Lewandowski, E.J. and Oriti, S.M., "Characterization of the Advanced Stirling Radioisotope Generator EU2," Proceedings of the Thirteenth International Energy Conversion Engineering Conference, AIAA, Orlando, FL, 2015.

4. Schwendeman, C., Tarau, C., Schifer, N., "Optimized Heat Pipe Backup Cooling System Tested With a Stirling Convertor," Proceedings of the Thirteenth International Energy Conversion Engineering Conference, AIAA, Orlando, FL, 2015.

5. Wilson, S.D., Schifer, N.A., Williams, Z.D., Metscher, J.F., "Overview of Stirling Technology Research at NASA Glenn Research Center," NASA/TM-2016-218909.

6. Wilson, S.D., Metscher, J.F., Schifer, N.A., "Active Vibration Reduction of the Advanced Stirling Convertor," Proceedings of the Fourteenth International Energy Conversion Engineering Conference, AIAA, Salt lake City, UT, 2016.

7. Dugala, G.M., et al., "Small Radioisotope Power System Testing at NASA Glenn Research Center," Proceedings of the Eleventh International Energy Conversion Engineering Conference, AIAA, San Jose, CA, 2013.

8. Shin, E.E., "Evaluation and Validation of Organic Materials for Advanced Stirling Convertors (ASCs): Overview," Proceedings of the Thirteenth International Energy Conversion Engineering Conference, AIAA, Orlando, FL, 2015.

9. Metscher, J.F., Geng, S.M., "Performance of a High Temperature 80W Linear Alternator for Stirling Convertors," Proceedings of the Fourteenth International Energy Conversion Engineering Conference, AIAA, Salt Lake City, UT, 2016.

10. Dugala, G.M., Taylor, L.M., et al., "Advanced Stirling Convertor Dual Convertor Controller Testing at NASA Glenn Research Center in the Radioisotope Power Systems System Integration Laboratory," Proceedings of the Thirteenth International Energy Conversion Engineering Conference, AIAA, Orlando, FL, 2015.

11. NASA Office of Space Science, "Enabling Exploration with Small Radioisotope Power Systems," JPL Pub 0410, September 2004.

12. Lee, Y.H., Bairstow, B., Amini, R., "Enabling Future Low-Cost Small Spacecraft Mission Concepts using Small Radioisotope Power Systems," SpaceOps Conference, AIAA, Pasadena, CA, 2014.

13. Lorenze, R. et al., "MASER: A Mars Meteorology and Seismology MiniNetwork Mission Concept Enabled by Milliwatt-RPS," 2014 IEEE, 978-1-4799-1622-1114.

14. Schmitz, P.C., Mason, L.S., Schifer, N.A., "Modular Stirling Radioisotope Generator," Proceedings of the Thirteenth International Energy Conversion Engineering Conference, AIAA, Orlando, FL, 2015.

15. Frerking, M.A., Beauchamp, P.M., JPL Technology Readiness Assessment Guideline," 2016 IEEE, 978-1-4673-7676-1/16.

16. NASA Office of the Chief Engineer, "NASA Systems Engineering Processes and Requirements," NPR 7123.1B, NASA, Washington, DC, effective April 18, 2013.

17. James Bilbro, Technology Assessment Calculator, JB Consulting International. 

